DOI: $10.19195 / 0137-1134.114 .35$

\author{
KATARZYNA KOKOCIŃSKA \\ Uniwersytet im. Adama Mickiewicza w Poznaniu \\ katarzyna.kokocinska@amu.edu.pl
}

\title{
KIERUNKI ROZWOJU NAUKI PUBLICZNEGO PRAWA GOSPODARCZEGO Z PERSPEKTYWY INSTYTUCJI I WARTOŚCI KONSTYTUCYJNYCH
}

\begin{abstract}
Abstrakt: Aksjologiczne uzasadnienie norm prawnych stanowi istotny obszar badań nad ogólnymi problemami prawa. Normy prawne powinny być osadzone w wartościach, a instytucje i wartości konstytucyjne muszą stanowić dla przyjmowanych regulacji prawnych zasadniczy punkt odniesienia, wyznaczający kierunek regulacji. W badaniach nad publicznym prawem gospodarczym szczególne znaczenie ma sposób ujęcia oraz konstytucyjna gwarancja ustroju gospodarczego. Podejście to ma bezpośrednie odniesienie do funkcjonowania administracji publicznej w gospodarce (administracja gospodarcza) jako dyrektywa określonego działania, wyznaczająca system wartości chronionych przez prawo publiczne gospodarcze. Konstytucja jest źródłem podstawowych wartości i instytucji prawnych, które nadają prawnym konstrukcjom jednolite dla całej nauki publicznego prawa gospodarczego znaczenie. Instytucje i wartości konstytucyjne porządkują działania administracji publicznej w szczególnej sferze, jaką jest gospodarka.
\end{abstract}

Słowa kluczowe: publiczne prawo gospodarcze, instytucje i wartości konstytucyjne, rozwój, wolność gospodarcza

Jednym z donioślejszych, a zarazem wyjątkowo interesującym kierunkiem badań w nauce publicznego prawa gospodarczego są analizy w ujęciu wartości i instytucji konstytucyjnych. Wśród nich szczególne znaczenie mają te, które stanowią o istocie tej dziedziny prawa, wyznaczają kierunki regulacji publicznego prawa gospodarczego.

Profesor Leon Kieres wskazuje na celowość wyznaczania nowych perspektyw badawczych poprzez charakteryzowanie obecności w regulacjach publicznego prawa gospodarczego ujęć konstytucyjnych oraz nadawania im przez Trybunał Konstytucyjny interpretacji znaczeniowej ${ }^{1}$.

${ }^{1}$ L. Kieres, Konstytucyjne publiczne prawo gospodarcze, „Ruch Prawniczy, Ekonomiczny i Socjologiczny" (dalej: RPEiS) 2014, z. 2, s. 192. 
Niewątpliwie instytucje i wartości konstytucyjne są dla przyjmowanych regulacji prawnych zasadniczym punktem odniesienia, ustalającym kierunek tych regulacji. Do zasad i wartości konstytucyjnych podkreślanych w publicznym prawie gospodarczym należą wskazane w tytule dedykowanej Szanownemu Jubilatowi księgi: ,praworządność”, „decentralizacja” (w kontekście publicznoprawnych uprawnień jednostek samorządu terytorialnego) i ,wolność gospodarcza” (przedsiębiorczość).

\section{UZASADNIENIE AKSJOLOGICZNE NORM PUBLICZNEGO PRAWA GOSPODARCZEGO}

Potrzeba uzasadnienia aksjologicznego norm prawnych coraz częściej stanowi przedmiot badań nad ogólnymi problemami prawa ${ }^{2}$. Podkreśla się, że normy prawne powinny być osadzone w wartościach, jednocześnie wskazując na potrzebę ich systematyzowania ${ }^{3}$. J. Zimmermann, z aksjologicznego punktu widzenia, dzieli wartości na trzy kategorie. Pierwsza to zbiór norm lub postulatów, które wprowadzają w obręb prawa (administracyjnego) wartości uniwersalne, leżące poza prawem. Drugą tworzą wartości niepochodzące z zewnątrz, a zatem ustalane przez prawo lub Konstytucję RP. To dzięki tym wartościom zdaniem J. Zimmermanna podmioty stosujące prawo działają na podstawie stałych założeń aksjologicznych. Trzecia kategoria to wartości chronione przez konkretną dziedzinę prawa, czyli wartości szczególne, do których ochrony prawo jest tworzone ${ }^{4}$.

Budowanie aksjologii publicznego prawa gospodarczego sprawia trudności ze względu na wyjątkowy przedmiot odniesienia regulacji normatywnych, którym jest gospodarka z wszystkimi jej uwarunkowaniami ${ }^{5}$. Znajduje to wyraz w sy-

2 Zob. m.in. M. Zdyb, Kryzys gospodarczy czy kryzys zaufania do państwa i prawa, [w:] Między tradycją a przyszłościa w nauce prawa administracyjnego. Księga jubileuszowa dedykowana Profesorowi Janowi Bociowi, red. J. Supernat, Wrocław 2009, s. 795-810; idem, Prawo gospodarcze publiczne i jego rola w oddziaływaniu na gospodarke, [w:] Prawne instrumenty oddziatywania na gospodarke, red. A. Powałowski, Warszawa 2016, s. 1-14; Wartości w prawie administracyjnym, red. J. Zimmermann, Warszawa 2015; J. Zimmermann, Aksjomaty prawa administracyjnego, Warszawa 2013; Dysfunkcje publicznego prawa gospodarczego, red. M. Zdyb, E. Kruk, G. Lubeńczuk, Warszawa 2018.

3 Na temat prawa administracyjnego zob. J. Zimmermann, op. cit., s. 74.

4 Ibidem, s. 75.

5 Zob. zbiór artykułów na temat prawa gospodarczego: Co to jest prawo gospodarcze?, RPEiS 1993, z. 1; a także T. Rabska, Działania administracji publicznej w świetle współczesnej koncepcji publicznego prawa gospodarczego, [w:] Instrumenty i formy prawne działania administracji gospodarczej, red. B. Popowska, K. Kokocińska, Poznań 2009, s. 16 n.; K. Strzyczkowski, Uwagi o zadaniach nauki i prawnych formach działania administracji gospodarczej, [w:] Instrumenty i formy prawne..., s. 35 n.; K. Kiczka, Konstytucjonalizacja publicznego prawa gospodarczego, [w:] Nowe problemy badawcze w teorii publicznego prawa gospodarczego (z uwzględnieniem samorzadu terytorialnego), red. L. Kieres, Wrocław 2010, s. 121; L. Kieres, Kierunki rozwoju regulacji publicznego prawa gospodarczego, [w:] 25 lat fundamentów wolności działalności gospodarczej. 
stemie wartości wyznaczanym dla stosunków zachodzących między państwem (administracją publiczną) a gospodarką — stosunków charakteryzujących się szczególną specyfiką, na co zwraca uwagę T. Rabska:

We współczesnych warunkach paradoksalnym jest istnienie przeciwstawnych (pozornie) dążeń, a jednocześnie potrzeba ich należytego powiązania. Mianowicie, postulatem stawianym prawu — od czasu transformacji ustrojowej — jest deregulacja i porządkowanie gospodarki — w coraz szerszym zakresie — regułom ekonomicznym. Z drugiej strony, to właśnie na państwie ciąży obowiązek wprowadzania nowych praw i kontrola ich realizacji w imię dobra wspólnego i ze względu na ważne interesy publiczne. Jednocześnie oczekuje się ochrony interesów indywidualnych, które mogą być różne od zbiorowych ${ }^{6}$.

Podobnie A. Chełmoński wskazuje, że wyznacznikiem wartości w obrębie regulacji publicznego prawa gospodarczego jest przyjęty system wartości będących odpowiedzią na rzeczywiste społeczne oczekiwania w sferze „gospodarowania”. Autor podkreśla, że głównym celem publicznego prawa gospodarczego jest stworzenie podstaw do urzeczywistnienia przez władzę publiczną dobra publicznego kosztem wolności i interesów jednostek; jednocześnie jednak to przepisy prawa publicznego chronią jednostkę przed nadużywaniem władztwa publicznego. Zgodnie $\mathrm{z}$ opinią badacza treść przyjętych regulacji prawnych wynika z przyjętych w danym czasie wartości społecznych, gospodarczych i politycznych, których realizacji oczekuje społeczeństwo. Wskazuje także na zmienność tych wartości w czasie, zarówno pod względem treści, ich hierarchii, jak i sposobu ich realizacji, podkreślając przy tym stabilność skutkującą trwałością ich ochrony przez prawo? Zdaniem K. Strzyczkowskiego

[d]ziałania administracji orientowane są przez określone, swoiste dla administracji, wzorce racjonalności, jakimi są: kierowanie się dobrem wspólnym, zasada efektywności, gospodarności, celowości, legalności, przejrzystości. Wartości te stanowią podstawę działań ingerencyjnych administracji w sferę gospodarki, konstytuowanej przez chronione konstytucyjnie wolności i prawa podmiotowe. Działania organów administracji gospodarczej orientowane są jednakże także przez zasady o charakterze ogólnoustrojowym; zasada demokratycznego państwa prawnego, zasada proporcjonalności, zasada państwa sprawiedliwości społecznej $[\ldots]^{8}$.

Poza wartościami uniwersalnymi katalog podstawowych, trwałych (w znaczeniu „niezmiennych”) wartości publicznego prawa gospodarczego tworzą wartości szczególne, chronione przez to prawo. W konsekwencji instytucje prawne,

Tendencje rozwojowe, red. J. Grabowski, K. Pokryszka, A. Hołody-Wydrzyńska, Katowice 2013, s. 330; K. Strzyczkowski, Prawo gospodarcze publiczne, Warszawa 2013, s. 51; J. Grabowski, Kryteria wyodrębnienia, przedmiot i zakres publicznego prawa gospodarczego, [w:] System Prawa Administracyjnego, t. 8A. Publiczne prawo gospodarcze, red. R. Hauser, Z. Niewiadomski, A. Wróbel, Warszawa 2013, s. 22 n. i wskazywana tam literatura.

6 T. Rabska, op. cit., s. 17.

7 A. Chełmoński, Zasady publicznego prawa gospodarczego, [w:] Zasady prawa gospodarczego. Materiały konferencyjne, red. A. Śmieja, Wrocław 1999, s. 50 n.

${ }^{8}$ K. Strzyczkowski, Uwagi o zadaniach nauki..., s. 54. 
struktury organizacji, formy działania administracji publicznej nie są obojętne aksjologicznie - przy ich kształtowaniu każdorazowo należy uwzględniać element wartościujący. Kreowanie katalogu wartości pomaga porządkować funkcjonowanie administracji publicznej. Zdaniem K. Kiczki konkretne wartości bądź zbiory wartości uzasadniają również wyodrębnienie w ramach publicznego prawa gospodarczego określonych składowych,

które stanowią podstawę sprawowania przez administrację gospodarczą pewnych funkcji w społecznej gospodarce rynkowej ${ }^{9}$ : policji gospodarczej, reglamentacji gospodarczej, regulacji gospodarczej, zarządu mieniem publicznym, planowania gospodarczego, wspierania gospodarki ${ }^{10}$.

Próba stworzenia katalogu szczegółowych wartości i ich systematyzowanie w obrębie publicznego prawa gospodarczego jest niezwykle trudnym zadaniem ${ }^{11}$ ze względu na wielodziedzinowość tej nauki prawa. Publiczne prawo gospodarcze charakteryzuje bowiem wielość podsystemów odnoszących się do różnych segmentów gospodarki (na przkład prawo sektorów infrastrukturalnych), a w ramach nich dalej idąca specjalizacja (prawo energetyczne, telekomunikacyjne, transportowe) $\mathrm{z}$ jednoczesną nadbudową teoretycznoprawną uzasadniającą potrzebę ich wyróżniania ${ }^{12}$. Wytłumaczenie takiego podejścia stanowi zazwyczaj podkreślana złożoność publicznoprawnych stosunków gospodarczych, wymagająca ciągłej adaptacji do zmieniających się uwarunkowań gospodarczo-społecznych, a w konsekwencji — swoistość przejętych rozwiązań prawnych ${ }^{13}$. Określane są one jako nietypowe bądź hybrydowe, będące tak zwanymi rozwiązaniami z pogranicza.

Postępująca specjalizacja w obrębie publicznego prawa gospodarczego jest nieunikniona, co przy tak szeroko zakreślonym przedmiocie jej regulacji po-

${ }^{9} \mathrm{Na}$ temat funkcji w publicznym prawie gospodarczym zob. M. Zdyb, Publiczne prawo gospodarcze, Kraków 1997; C. Kosikowski, Publiczne prawo gospodarcze Polski i Unii Europejskiej, Warszawa 2007; A. Borkowski et al., Administracyjne prawo gospodarcze, Wrocław 2005; K. Strzyczkowski, Prawo gospodarcze publiczne, Warszawa 2011; Prawo gospodarcze. Zagadnienia administracyjnoprawne, red. H. Gronkiewicz-Waltz, M. Wierzbowski, Warszawa 2011; System Prawa Administracyjnego, t. 8A. Publiczne prawo gospodarcze i wskazywana tam literatura; Publiczne prawo gospodarcze. Zarys wyktadu, red. R. Blicharz, Warszawa 2015; Prawo gospodarcze publiczne, red. A. Powałowski, Warszawa 2015.

${ }^{10} \mathrm{~K}$. Kiczka, Wartości w publicznym prawie gospodarczym (zagadnienia wybrane), [w:] Wartości w prawie administracyjnym, red. J. Zimmermann, Warszawa 2015, s. 250. Zob. także Funkcje wspótczesnej administracji gospodarczej, red. B. Popowska, Poznań 2006; a w szczególności K. Kiczka, Funkcje administracji gospodarczej jako przedmiot badań, [w:] Funkcje współczesnej administracji..., s. 39-60.

11 Również ze względu na brak jednolitości struktury publicznego prawa gospodarczego. Obejmuje zarówno normy prawne ustrojowe, normy materialnego prawa gospodarczego, jak i normy proceduralne. Zob. na ten temat T. Rabska, op. cit., s. 15-17.

12 Zob. m.in. Instrumenty i formy prawne...; Nowe problemy badawcze...; 25 lat fundamentów wolności...; Prawne instrumenty oddziaływania...

13 Zob. L. Kieres, Odesłania do publicznego prawa gospodarczego - wartości powszechnie uznawane $i$ wartości szczególne, [w:] 25 lat fundamentów wolności..., s. 289-301. 
woduje trudności w poszukiwaniu wspólnych wyróżników publicznego prawa gospodarczego - wspólnych wartości. Jest to dziedzina, w której obrębie z wyjątkową intensywnością zachodzą zmiany stanowiące odzwierciedlenie ewolucji funkcji państwa wobec gospodarki ${ }^{14}$. Zjawisko to nie pozostaje bez wpływu na wyodrębniane w publicznym prawie gospodarczym wartości i instytucje prawne, które należy rozpatrywać w związku i na tle aktualnych stosunków społeczno-gospodarczych ${ }^{15}$.

Publiczne prawo gospodarcze jako odrębna gałąź prawa ma już jednak ugruntowane miejsce w systemie prawa, co pozwala na przyjmowanie rozwiązań o charakterze systemowym, w tym tworzenie wartości uniwersalnych w obrębie publicznego prawa gospodarczego.

Podobnie jak w innych dziedzinach prawa, tak i w publicznym prawie gospodarczym występują wartości o charakterze uniwersalnym dla całego porządku prawnego: dobro człowieka, sprawiedliwość, moralność, jak i te o szczególnym znaczeniu w obszarze regulacji prawa publicznego: legalność, sprawność, celowość działania. Elementem tego systemu są również wartości, które należy realizować bądź są wartościami prawnie chronionymi regulacjami z obszaru publicznego prawa gospodarczego, a wynikające $\mathrm{z}$ ustawowo określonych powinności państwa ${ }^{16}$.

\section{Łącznie tworzą system wartości tej dziedziny prawa.}

Dlatego w badaniach nad publicznym prawem gospodarczym (tu: w obszarze jego wartości) szczególne znaczenie mają, podkreślane przez L. Kieresa, sposób ujęcia oraz konstytucyjna gwarancja ustroju gospodarczego. Podejście to ma bezpośrednie odniesienie do funkcjonowania administracji publicznej w gospodarce (administracja gospodarcza) jako dyrektywa określonego działania, wyznaczająca system wartości chronionych przez prawo publiczne gospodarcze ${ }^{17}$.

14 Funkcje współczesnej administracji...; a w szczególności K. Kiczka, Funkcje administracji gospodarczej..., s. 39-60.

15 Wyodrębnione i utrwalane przez nas w opracowaniach naukowych instytucje prawne wymagają ciągłej naukowej weryfikacji. Przyczyną takiego stanu rzeczy jest niestabilność całego systemu prawa. Nawet jeśli przepisy stanowiące podstawę wyodrębnienia określonej instytucji prawnej ulegają nieznacznym przeobrażeniom, to zmiana kontekstu społecznego czy gospodarczego, w którym ten zespół powiązanych norm prawnych obowiązuje, może nadać im nowe lub zmienione znaczenie albo sprawić, że będą pełnić inne funkcje niż dotychczas. Przykładem takich instytucji prawnych jest „reglamentacja” — T. Rabska, Czy jeszcze „,reglamentacja administracyjna”? Wypowiedź dyskusyjna, [w:] Księga jubileuszowa Prof. dr. hab. Stanisława Jędrzejewskiego, red. W. Szwajdler, H. Nowicki, Toruń 2009, s. 441-455. Zob. także. Dysfunkcje publicznego prawa...

${ }^{16}$ K. Kokocińska, Funkcjonalność i dysfunkcjonalność przepisów publicznego prawa gospodarczego z perspektywy kryterium wartości (zagadnienia ogólne), [w:] Dysfunkcje publicznego prawa..., s. 25-39.

17 L. Kieres wskazuje, odwołując się do postanowienia TK, że „[w]olność gospodarcza (działalności gospodarczej) wyznacza sytuację jednostki (osoby fizycznej, jednostki organizacyjnej — podmiotów prawa) w związku z podejmowaniem lub wykonywaniem przedsiębiorczości. Wolność tę wywodzimy z godności osoby fizycznej (art. 30 Konstytucji). Uznanie godności przez jej uwzględnienie w kategoriach i ujęciach prawnych oznacza zarazem poszanowanie zakotwiczonej w jej treści wolności gospodarczej. Podobnej weryfikacji podlega sytuacja jednostek organizacyjnych, które 


\section{AKSJOLOGIA STOSUNKÓW SPOŁECZNO-GOSPODARCZYCH}

Przyjęty i zhierarchizowany system wartości w przestrzeni regulacji normatywnej, jaką są stosunki zachodzące na styku „państwo” i „gospodarka”, stanowią o istocie publicznego prawa gospodarczego. Wśród nich zasadnicze znaczenie z punktu widzenia tej dziedziny prawa mają te konstytucyjne rozwiązania, które określają ustrój gospodarczy (art. 20 Konstytucji RP).

Na gruncie Konstytucji Rzeczypospolitej Polskiej aksjologię stosunków społeczno-gospodarczych wyznaczają konstytucyjne zasady ustroju społeczno-gospodarczego państwa, a w szczególności zasada społecznej gospodarki rynkowej ${ }^{18}$. Zasada ta, wraz z konstytucyjnie gwarantowanymi wolnościami i prawami ekonomicznymi, określa model gospodarki (model ekonomiczny), w którym dopuszcza się korygowanie praw rynku przez państwo w celu realizacji określonych potrzeb społecznych niemożliwych do spełnienia przy całkowicie swobodnym funkcjonowaniu praw rynkowych, ale przy jednoczesnym ich poszanowaniu ${ }^{19}$. Społeczna gospodarka rynkowa jest równocześnie wyrazem konstytucyjnego obrazu ładu społecznego opartego na wolności gospodarczej i własności prywatnej, a także solidarności, dialogu i współpracy partnerów społecznych. C. Banasiński, wskazując skutki konstytucjonalizacji modelu społecznej gospodarki rynkowej, podnosi, że przepis art. 20 Konstytucji RP nie daje jednak państwu legitymacji do

są uprawnione (zobowiązane) do podejmowania i wykonywania działalności gospodarczej (przedsiębiorczości). Źródłem ich wolności gospodarczej jest bowiem wolność osoby ludzkiej, jeżeli za sytuacją jednostek organizacyjnych kryją się wartości, które wiążemy z jednostkami (osobami fizycznymi)", idem, Konstytucyjne publiczne prawo, s. 193, w sprawie postanowienia Trybunału Konstytucyjnego (dalej: TK) z dnia 23 lutego 2005 r., TS 35/04, OTK ZU 2005, nr 1/B, poz. 26.

18 Zob. m.in. wyrok TK z dnia 8 kwietnia 1998 r., K 10/97, OTK ZU 1998, nr 3, poz. 29; wyrok TK z dnia 30 stycznia 2001 r., K 17/00, OTK ZU 2001, nr 1, poz. 4.

19 Zarówno pojęcie, jak i ocena modelu społecznej gospodarki rynkowej były przedmiotem szerokich badań naukowych. Zob. m.in. D. Grosser, Społeczna gospodarka rynkowa - bezpieczeństwo społeczne, Warszawa 1993; R. Skarzyński, Państwo i społeczna gospodarka rynkowa, Warszawa 1994; A. Adamczyk, Definicja i istota społecznej gospodarki rynkowej, [w:] Społeczna gospodarka rynkowa, red. R.W. Włodarczyk, Warszawa 2010; T. Kocowski, Reglamentacja forma interwencjonizmu państwowego w społecznej gospodarce rynkowej, [w:] Państwo i rynek. Obszary zawodności, red. U. Kalina-Prasznic, Wrocław 2011, s. 53-81; C. Kosikowski, op. cit., Warszawa 2007, s. 35-36; G. Przesławska, Społeczna gospodarka rynkowa, [w:] Regulowana gospodarka rynkowa, red. U. Kalina-Prasznic, Kraków 2003, s. 69-93; P. Pysz, Społeczna gospodarka rynkowa. Ordoliberalna koncepcja polityki gospodarczej, Warszawa 2008; K. Strzyczkowski, Konstytucyjna zasada spolecznej gospodarki rynkowej jako podstawa tworzenia i stosowania prawa, [w:] Zasady ustroju społecznego i gospodarczego w procesie stosowania Konstytucji, red. C. Kosikowski, Warszawa 2005, s. 213-236; K. Strzyczkowski, Prawo gospodarcze publiczne, Warszawa 2008, s. 64-71; K. Sobczak, Gospodarka rynkowa a władza publiczna, Warszawa 1997, passim; T. Włudyka, Model społecznej gospodarki rynkowej a transformacja ustrojowa polskiej gospodarki. Analiza prawnogospodarcza, Kraków 2002, passim; A. Żurawik, Zasady ogólne publicznego prawa gospodarczego, [w:] System Prawa Administracyjnego, t. 8A. Publiczne prawo gospodarcze, s. 439-448 i wskazywana tam literatura. 
dowolnego kształtowania tego modelu. Artykuł ten stanowi generalną dyrektywę kierunkową ${ }^{20}$ - przez pryzmat ujętych w niej wartości konstytucyjnych, które prawo powinno realizować oraz chronić, wyznaczane są cele i funkcje publicznego prawa gospodarczego.

Wskazane ujęcie stanowiło w działalności naukowo-badawczej L. Kieresa istotny wątek. Profesor podkreśla przy tym często, że każda regulacja jest zakorzeniona w instytucjach i wartościach konstytucyjnych, a wśród nich za szczególną instytucję implementowaną przez publiczne prawo gospodarcze uznaje wolność działalności gospodarczej ${ }^{21}$. W swoich rozważaniach wielokrotnie zaznacza, że wolność działalności gospodarczej stanowi przedmiot ujęcia normatywnego przede wszystkim w rozwiązaniach konstytucyjnych ${ }^{22}$. To jakże istotne stwierdzenie znajduje uzasadnienie wobec braku wyróżnienia ustawowej definicji „wolności gospodarczej" bądź jej charakteryzowania poprzez definiowanie istotnych cech tej instytucji prawnej ${ }^{23} \mathrm{w}$ ustawodawstwie zwykłym. L. Kieres podkreśla, że

[b]rak zainteresowania ustrojodawcy co do wyróżnienia wolności gospodarczej czy ujęcia jej cech znamiennych, wyrażony przez odesłanie do ustawodawstwa zwykłego jako właściwego do nadawania wolności określonych treści, oznaczałoby w istocie uznanie jej za wartość, której miejsce

20 C. Banasiński, Konstytucyjne podstawy ustroju gospodarczego, [w:] Prawo gospodarcze. Zagadnienia administracyjnoprawne, s. 42. Na temat ustroju gospodarczego zob. także T. Rabska, Gospodarka rynkowa i jej zasady, [w:] Konstytucja i gospodarka, wyb. i oprac. P. Kaczanowski, Warszawa 1995, s. 80; A. Szmyt, O normowaniu podstaw ustroju gospodarczego Rzeczypospolitej Polskiej, „Gdańskie Studia Prawnicze” 5, 1999, s. 403; Zasady ustroju społecznego i gospodarczego...; K. Kiczka, Funkcje administracji gospodarczej..., s. 56-59; idem, Uwagi o wolności działalności gospodarczej, [w:] Księga jubileuszowa..., s. 231-234. Zob. też wyrok TK z dnia 30 stycznia 2000 r., K 17/00, OTK 2001, nr 1, poz. 4. Trybunał Konstytucyjny wskazuje w nim, że społeczna gospodarka rynkowa ma swoje szersze podstawy niż art. 20 Konstytucji RP, uwypuklając potrzebę jego odczytywania w kontekście pozostałych przepisów konstytucyjnych, w tym formułujących zasadę demokratycznego państwa prawnego i sprawiedliwości społecznej (art. 2 Konstytucji RP). Z kolei w wyroku z dnia 28 stycznia 2003 r. (K 2/02, OTK-A 2003, nr 1, poz. 4) TK podkreśla konieczność dokonywania interpretacji art. 20 Konstytucji RP z uwzględnieniem europejskiego standardu, jaką jest zasada interpretacji przyjaznej prawu europejskiemu; por. wyrok TK z dnia 28 marca 2000 r., K 27/99, OTK 2000, nr 2, poz. 62. Na ten temat zob. P. Sarnecki, Prawo konstytucyjne RP, Warszawa 1999, s. 39; K. Kiczka, Konstytucjonalizacja publicznego prawa..., s. 128 n.; A. Żurawik, op. cit., s. $445-448$.

${ }^{21}$ L. Kieres, Konstytucyjne publiczne prawo..., s. 191; zob. także M. Szydło, Wolność dziatalności gospodarczej jako prawo podstawowe, Bydgoszcz-Wrocław 2011, s. 55-56.

22 Zob. m.in. wyrok TK z dnia 5 kwietnia 2001 r., P 26/09, OTK ZU 2011, nr 3/A; wyrok TK z dnia 29 kwietnia 2003 r., SK 24/02, OTK ZU 2003, nr 4/A.

23 Według Z. Ziembińskiego instytucja prawna oznacza ,pewien zespół norm prawnych wydzielony jako odrębna całość ze względu na to, że normy te mają zmierzać do realizacji ustawowo wskazanego celu”, idem, Szkice z metodologii szczegółowych nauk prawnych, „Metodologia Nauk” 24, 1983, s. 88. Autor wskazuje również inne sposoby określenia ,instytucji” jako zespół działań wyznaczanych przez wydzielony zespół norm (funkcjonalne pojmowanie instytucji) czy też zespół osób działających w myśl wskazań lub na podstawie upoważnień zawartych w wyodrębnionym zespole norm (personalne pojmowanie instytucji). 
i znaczenie w katalogu instytucji prawnych gospodarki rynkowej wyznaczają koniunkturalne przyjmowane poglądy i stanowiska leżące $\mathrm{u}$ ich podstaw oceny, formułowane $\mathrm{w}$ wyniku sporów o wartości polityczne ${ }^{24}$.

Pogląd ten należy traktować w kategoriach uniwersalnej reguły odnoszącej się do podstawowych instytucji publicznego prawa gospodarczego - instytucji wyznaczających tożsamość tej dziedzina prawa ${ }^{25}$.

$$
* * *
$$

Uwzględnianie dorobku orzeczniczego polskiego sądu konstytucyjnego, a także konstytucyjnego ujęcia określonych instytucji i wartości w procesie stanowienia prawa szczegółowego dla publicznoprawnych i prywatnoprawnych stosunków w gospodarce stanowiło jeden z zasadniczych postulatów L. Kieresa. Istotnym wkładem w rozwój nauki publicznego prawa gospodarczego są koncepcje autorstwa Profesora związane z potrzebą osadzania regulacji publicznego prawa gospodarczego w odniesieniu do aksjologii konstytucji.

Dokonując oceny poprawności rozwiązań normatywnych, którą zazwyczaj przeprowadza się w stosunku do zespołu przepisów prawnych w obrębie wybranego zagadnienia unormowanego w trybie publicznoprawnym, nie można pomijać kontekstu systemowego. Podejmowanie analiz prawnych w odniesieniu do systemu publicznego prawa gospodarczego, którego zasadniczym elementem są konstytucyjne zasady, pozwala właściwie ocenić poprawność legislacji. Oznacza to, że zasady konstytucyjne powinny znaleźć odniesienie w merytorycznej treści aktów, niekoniecznie w ramach szczegółowych regulacji, ale przez ich odwołanie do celów tej regulacji bądź sposobu ujęcia realizacji określonego interesu publicznego. Uwzględnianie w badaniach nad publicznym prawem gospodarczym założeń ustroju gospodarczego w ujęciu konstytucyjnych zasad ${ }^{26}$ jest niezbędne również ze względu na ich istotne oddziaływanie na mechanizm funkcjonowania organów administracji publicznej ${ }^{27}$. Czynnikiem wpływającym na racjonalne i skuteczne podejmowanie działań przez administrację publiczną jest wypracowanie spójnej koncepcji rozwiązań o charakterze instytucjonalnym, w tym podstawowych reguł działania. W publicznym prawie gospodarczym punktem ich odniesienia powinny być konstytucyjne zasady ustroju gospodarczego państwa.

Dlatego za szczególny wkład L. Kieresa w rozwój nauki publicznego prawa gospodarczego należy uznać podkreślanie przez Niego fundamentalnego znaczenia, w rozważaniach nad organizacją i funkcjonowaniem struktur publicznych

24 L. Kieres, Konstytucyjne publiczne prawo..., s. 191.

25 L. Kieres, Kierunki rozwoju regulacji..., s. 331.

26 Zob. K. Strzyczkowski, Zasada państwa sprawiedliwości społecznej jako zasada publicznego prawa gospodarczego, RPEiS 2007, z. 4, s. 11 n.

27 K. Kokocińska, Prawny mechanizm prowadzenia polityki rozwoju $w$ zdecentralizowanych strukturach władzy publicznej, Poznań, 2014, s. 308. 
w gospodarce, odniesienia do postanowień ustawy konstytucyjnej. Bez nawiązywania do konstytucyjnych treści nie jest bowiem możliwa pełna analiza regulacji normatywnych. Konstytucja jest źródłem podstawowych wartości i instytucji prawnych, które nadają określonym konstrukcjom prawnym jednolity, wspólny całej nauce publicznego prawa gospodarczego sens prawny (znaczenie). Konstytucja tworzy podstawy budowania struktur organizacyjnych państwa, zachodzących między nimi stosunków wynikających z podziału zadań i kompetencji oraz - co istotne - sposobu i zakresu uzasadnionego wkraczania państwa w stosunki gospodarcze $^{28}$. Instytucje i wartości konstytucyjne porządkują działania administracji publicznej w szczególnej sferze, jaką jest gospodarka.

\title{
DIRECTIONS OF THE DEVELOPMENT OF THE SCIENCE OF PUBLIC ECONOMIC LAW FROM THE PERSPECTIVE OF CONSTITUTIONAL INSTITUTIONS AND VALUES
}

\author{
Summary
}

The axiological justification of legal norms is an important area of research on general legal problems. Legal norms should be embedded in values, and constitutional institutions and values constitute the basic point of reference for adopted legal regulations, setting the direction of regulation. In the research on public economic law, the method of recognition and the constitutional guarantee of the economic system are of particular importance. This approach has a direct reference to the functioning of public administration in the economy (economic administration) as a directive of its specific activity, defining a system of values protected by public economic law. Constitution is the source of fundamental values and legal institutions that give legal constructs a uniform meaning for the whole science of public economic law. Institutions and constitutional values order the actions of public administration in a specific sphere, which is the economy.

Keywords: public economic law, constitutional institutions and values, development, economic freedom

\section{BIBLIOGRAFIA}

25 lat fundamentów wolności działalności gospodarczej. Tendencje rozwojowe, red. J. Grabowski, K. Pokryszka, A. Hołody-Wydrzyńska, Katowice 2013.

Adamczyk A., Definicja i istota społecznej gospodarki rynkowej, [w:] Społeczna gospodarka rynkowa, red. R.W. Włodarczyk, Warszawa 2010.

Banasiński C., Konstytucyjne podstawy ustroju gospodarczego, [w:] Prawo gospodarcze. Zagadnienia administracyjnoprawne, red. H. Gronkiewicz-Waltz, M. Wierzbowski, wyd. 2 zmien., Warszawa 2011.

28 Zob. m.in. wyrok Sądu Najwyższego z dnia 9 sierpnia 2006 r., III SK 6/06; wyrok TK z dnia 10 kwietnia 2001 r., U 7/00, OTK ZU 2001, nr 3; wyrok TK z dnia 21 kwietnia 2004 r., K 33/03, OTK ZU 2004, nr 4/A. 
Borkowski A. et al., Administracyjne prawo gospodarcze, Wrocław 2005.

Dysfunkcje publicznego prawa gospodarczego, red. M. Zdyb, E. Kruk, G. Lubeńczuk, Warszawa 2018.

Europeizacja publicznego prawa gospodarczego, red. H. Gronkiewicz-Waltz, K. Jaroszyński, Warszawa 2011.

Funkcje współczesnej administracji gospodarczej, red. B. Popowska, Poznań 2006.

Grabowski J., Kryteria wyodrębnienia, przedmiot i zakres publicznego prawa gospodarczego, [w:] System Prawa Administracyjnego, t. 8A. Publiczne prawo gospodarcze, red. R. Hauser, Z. Niewiadomski, A. Wróbel, Warszawa 2013.

Grosser D., Społeczna gospodarka rynkowa - bezpieczeństwo społeczne, Warszawa 1993.

Instrumenty i formy prawne działania administracji gospodarczej, red. B. Popowska, K. Kokocińska, Poznań 2009.

Kiczka K., Funkcje administracji gospodarczej jako przedmiot badań, [w:] Funkcje współczesnej administracji gospodarczej, red. B. Popowska, Poznań 2006.

Kiczka K., Konstytucjonalizacja publicznego prawa gospodarczego, [w:] Nowe problemy badawcze $w$ teorii publicznego prawa gospodarczego (z uwzględnieniem samorzadu terytorialnego), red. L. Kieres, Wrocław 2010.

Kiczka K., Uwagi o wolności działalności gospodarczej, [w:] Ksiegga jubileuszowa Prof. dr. hab. Stanisława Jędrzejewskiego, red. W. Szwajdler, H. Nowicki, Torun 2009.

Kiczka K., Wartości w publicznym prawie gospodarczym (zagadnienia wybrane), [w:] Wartości w prawie administracyjnym, red. J. Zimmermann, Warszawa 2015.

Kieres L., Kierunki rozwoju regulacji publicznego prawa gospodarczego, [w:] 25 lat fundamentów wolności działalności gospodarczej. Tendencje rozwojowe, red. J. Grabowski, K. Pokryszka, A. Hołody-Wydrzyńska, Katowice 2013.

Kieres L., Konstytucyjne publiczne prawo gospodarcze, „Ruch Prawniczy, Ekonomiczny i Socjologiczny” 2014, z. 2.

Kieres L., Odestania do publicznego prawa gospodarczego - wartości powszechnie uznawane i wartości szczególne, [w:] Europeizacja publicznego prawa gospodarczego, red. H. Gronkiewicz-Waltz, K. Jaroszyński, Warszawa 2011.

Kocowski T., Reglamentacja forma interwencjonizmu państwowego w społecznej gospodarce rynkowej, [w:] Państwo i rynek. Obszary zawodności, red. U. Kalina-Prasznic, Wrocław 2011.

Kokocińska K., Funkcjonalność i dysfunkcjonalność przepisów publicznego prawa gospodarczego z perspektywy kryterium wartości (zagadnienia ogólne), [w:] Dysfunkcje publicznego prawa gospodarczego, red. M. Zdyb, E. Kruk, G. Lubeńczuk, Warszawa 2018.

Kokocińska K., Prawny mechanizm prowadzenia polityki rozwoju w zdecentralizowanych strukturach władzy publicznej, Poznań 2014.

Kosikowski C., Publiczne prawo gospodarcze Polski i Unii Europejskiej, Warszawa 2007.

Nowe problemy badawcze w teorii publicznego prawa gospodarczego (z uwzględnieniem samorzadu terytorialnego), red. L. Kieres, Wrocław 2010.

Prawne instrumenty oddziaływania na gospodarke, red. A. Powałowski, Warszawa 2016.

Prawo gospodarcze publiczne, red. A. Powałowski, Warszawa 2015.

Prawo gospodarcze. Zagadnienia administracyjnoprawne, red. H. Gronkiewicz-Waltz, M. Wierzbowski, wyd. 2 zmien., Warszawa 2011.

Przesławska G., Społeczna gospodarka rynkowa, [w:] Regulowana gospodarka rynkowa, red. U. Kalina-Prasznic, Kraków 2003.

Publiczne prawo gospodarcze. Zarys wyktadu, red. R. Blicharz, Warszawa 2015.

Pysz P., Społeczna gospodarka rynkowa. Ordoliberalna koncepcja polityki gospodarczej, Warszawa 2008.

Rabska T., Czy jeszcze „reglamentacja administracyjna”? Wypowiedź dyskusyjna, [w:] Księga jubileuszowa Prof. dr. hab. Stanisława Jędrzejewskiego, red. W. Szwajdler, H. Nowicki, Toruń 2009.

Przegląd Prawa i Administracji 114, 2018

(C) for this edition by CNS 
Rabska T., Działania administracji publicznej w świetle współczesnej koncepcji publicznego prawa gospodarczego, [w:] Instrumenty i formy prawne działania administracji gospodarczej, red. B. Popowska, K. Kokocińska, Poznań 2009.

Rabska T., Gospodarka rynkowa i jej zasady, [w:] Konstytucja i gospodarka, wyb. i oprac. P. Kaczanowski, Warszawa 1995.

Sarnecki P., Prawo konstytucyjne RP, Warszawa 1999.

Skarzyński R., Państwo i społeczna gospodarka rynkowa, Warszawa 1994.

Sobczak K., Gospodarka rynkowa a władza publiczna, Warszawa 1997.

Strzyczkowski K., Konstytucyjna zasada społecznej gospodarki rynkowej jako podstawa tworzenia $i$ stosowania prawa, [w:] Zasady ustroju społecznego i gospodarczego w procesie stosowania Konstytucji, red. C. Kosikowski, Warszawa 2005.

Strzyczkowski K., Prawo gospodarcze publiczne, Warszawa 2008, 2011, 2013.

Strzyczkowski K., Uwagi o zadaniach nauki o prawnych formach działania administracji gospodarczej, [w:] Instrumenty i formy prawne działania administracji gospodarczej, red. B. Popowska, K. Kokocińska, Poznań 2009.

Strzyczkowski K., Zasada państwa sprawiedliwości społecznej jako zasada publicznego prawa gospodarczego, „Ruch Prawniczy, Ekonomiczny i Socjologiczny” 2007, z. 4.

System Prawa Administracyjnego, t. 8A. Publiczne prawo gospodarcze, red. R. Hauser, Z. Niewiadomski, A. Wróbel, Warszawa 2013.

Szmyt A., O normowaniu podstaw ustroju gospodarczego Rzeczypospolitej Polskiej, „Gdańskie Studia Prawnicze" 5, 1999.

Szydło M., Wolność działalności gospodarczej jako prawo podstawowe, Bydgoszcz-Wrocław 2011. Wartości w prawie administracyjnym, red. J. Zimmermann, Warszawa 2015.

Włudyka T., Model społecznej gospodarki rynkowej a transformacja ustrojowa polskiej gospodarki. Analiza prawnogospodarcza, Kraków 2002.

Zasady ustroju społecznego i gospodarczego w procesie stosowania Konstytucji, red. C. Kosikowski, Warszawa 2005.

Zdyb M., Kryzys gospodarczy czy kryzys zaufania do państwa i prawa, [w:] Między tradycją a przyszłościa w nauce prawa administracyjnego. Księga jubileuszowa dedykowana Profesorowi Janowi Bociowi, red. J. Supernat, Wrocław 2009.

Zdyb M., Prawo gospodarcze publiczne i jego rola w oddziatywaniu na gospodarke, [w:] Prawne instrumenty oddziaływania na gospodarke, red. A. Powałowski, Warszawa 2016.

Zdyb M., Publiczne prawo gospodarcze, Kraków 1997.

Ziembiński Z., Szkice z metodologii szczegółowych nauk prawnych, „Metodologia Nauk”24, 1983.

Zimmermann J., Aksjomaty prawa administracyjnego, Warszawa 2013.

Żurawik A., Zasady ogólne publicznego prawa gospodarczego, [w:] System Prawa Administracyjnego, t. 8A. Publiczne prawo gospodarcze, red. R. Hauser, Z. Niewiadomski, A. Wróbel, Warszawa 2013. 